ISSN 1678-3921

Journal homepage: www.embrapa.br/pab

For manuscript submission and journal contents, access: www.scielo.br/pab



\section{Herbage accumulation and canopy structure during stockpiling of Marandu, Piatã, Xaraés, and Paiaguás brachiariagrass cultivars}

\begin{abstract}
The objective of this work was to compare herbage accumulation and canopy structural characteristics during the stockpiling period of the Marandu, Piatã, Xaraés, and Paiaguás cultivars of Urochloa brizantha. The experimental design was completely randomized, with three replicates. The experiment was repeated for two years (2017 and 2018), under mechanical cutting conditions, and the canopies were stockpiled for 90 days, from March to June. In the first year, forage mass was higher for the Xaraés and Paiaguás cultivars; however, in the second year, Xaraés showed a forage mass higher than that of the other cultivars. The number of vegetative tillers at the end of the stockpiling period was higher for Paiaguás, contrary to what was observed for number of reproductive tillers. The herbage accumulation rate was higher for the Paiaguás and Xaraés cultivars. The Paiaguás grass stands out for its high herbage accumulation rate during the stockpiling period and for its higher number of vegetative tillers and lower number of reproductive tillers than that of the other cultivars.
\end{abstract}

Index terms: Urochloa brizantha, canopy height, flowering, herbage mass, tiller.

\section{Acúmulo de forragem e estrutura dos dosséis durante o diferimento das cultivares Marandu, Piatã, Xaraés e Paiaguás de capim-braquiária}

Resumo - O objetivo deste trabalho foi comparar o acúmulo de forragem e as características estruturais de dosséis durante o período de diferimento das cultivares Marandu, Piatã, Xaraés e Paiaguás de Urochloa brizantha. O delineamento experimental foi inteiramente casualizado, com três repetições. O experimento foi repetido por dois anos (2017 e 2018), sob condição de corte mecânico, e o dossel foi diferido por 90 dias, de março a junho. No primeiro ano, a massa de forragem foi maior para as cultivares Xaraés e Paiaguás; porém, no segundo ano, Xaraés apresentou massa de forragem maior do que a das demais cultivares. O número de perfilhos vegetativos no final do período de diferimento foi maior para Paiaguás, contrariamente ao que foi observado para número de perfilhos reprodutivos. Já a taxa de acúmulo de forragem foi maior para as cultivares Paiaguás e Xaraés. O capim Paiaguás se destaca por sua alta taxa de acúmulo de forragem durante o período de diferimento e por seu maior número de perfilhos vegetativos e menor número de perfilhos reprodutivos do que os das outras cultivares.

Termos para indexação: Urochloa brizantha, altura do dossel, florescimento, massa de forragem, perfilho. 


\section{Introduction}

Stockpiling consists of excluding an area of pasture from grazing, usually in late summer and/or in autumn in the Southeastern and Midwestern regions of Brazil (Silva et al., 2016; Afonso et al., 2018), in order to guarantee herbage mass to be grazed during the period of scarcity, minimizing the negative effects of the seasonality of herbage accumulation (Nave et al., 2016). Herbage accumulation during the stockpiling period influences the herbage mass available to animals in the dry season and, therefore, is one of the determinants of the carrying capacity of a stockpiled pasture (Santos et al., 2018), whose structural characteristics affect animal performance (Silva et al., 2016; Afonso et al., 2018).

For stockpiling, grasses with a lower height, thin stem, high growth during autumn, and low rate of reduction in nutritional value during growth are recommended (Santos et al., 2018). In general, these characteristics are present in grasses of the genus Urochloa (Syn. Brachiaria), such as the species Urochloa brizantha (A.Rich.) R.D.Webster, which has several cultivars available in the market: Marandu, Piatã, Xaraés, and Paiaguás. It is also appropriate to choose forage plants that do not flower strongly during the stockpiling period (Santos et al., 2018). In this sense, the Piatã (Nantes et al., 2013) and Paiaguás (Euclides et al., 2016) cultivars are suitable for stockpiling since they have early flowering; the Paiaguás cultivar also produces more forage with a better nutritional value during the dry season (Euclides et al., 2016). Although the Xaraés cultivar has late flowering (Valle et al., 2004), which would make it inappropriate for stockpiled pasture, it has a high potential for herbage accumulation (Flores et al., 2008). The Marandu cultivar has sparse flowering from late spring to early autumn (Euclides et al., 2008), but, if the stockpiling period starts at the end of March, this forage plant may also be a good option (Silva et al., 2016; Afonso et al., 2018).

Of the $U$. brizantha cultivars, research work on stockpiling pasture has been carried out predominantly with the Marandu and Piatã cultivars. For these grasses, there are scientific studies that allow understanding the effects of stockpiling period (Gouveia et al., 2017; Rocha et al., 2020), canopy height before stockpiling (Sousa et al., 2013; Nogueira et al., 2020), and nitrogen fertilization on stockpiled canopies (Alves et al.,
2019; Sousa et al., 2019). However, for the Xaraés and Paiaguás cultivars, there is still no available scientific information to guide the management of these grasses under stockpiling.

Furthermore, although the importance of the adequate choice of a forage plant for use in stockpiled pastures is recognized (Silva et al., 2016; Santos et al., 2018), there are no known comparative studies in the scientific literature on the productive and structural responses of the Marandu, Piatã, Xaraés, and Paiaguás cultivars subjected to stockpiling. In most research works (Sousa et al., 2013, 2019; Gouveia et al., 2017; Alves et al., 2019; Nogueira et al., 2020), only a few of these cultivars were evaluated under different stockpiling management conditions. As a result, the possible differences between the Marandu, Piatã, Xaraés, and Paiaguás cultivars regarding forage accumulation, flowering degree, and morphological composition of stockpiled forage are still unknown.

The objective of this work was to compare herbage accumulation and canopy structural characteristics during the stockpiling period of the Marandu, Piatã, Xaraés, and Paiaguás cultivars of Urochloa brizantha.

\section{Materials and Methods}

The experiment was conducted from October 2016 to June 2018, during which the study was repeated twice - first year, in 2017; and second year, in 2018. The experiment was carried out at the Capim Branco experimental farm, at Universidade Federal de Uberlândia (18 55'21"S, 48 16'38'W, at 863 m above sea level). According to Köppen's classification, the climate is Aw, a tropical savannah, with a well-defined rainy season from October to March and a dry season from April to September (Alvares et al., 2013). Data on climatic conditions during the experimental period were monitored at a meteorological station located approximately $200 \mathrm{~m}$ from the experimental area (Figure 1). The data were used to calculate the monthly water balance of the soil (Figure 2), considering a 50 $\mathrm{mm}$ water storage capacity (Thornthwaite \& Mather, 1955).

The relief of the experimental area is flat, and the soil was classified as a Latossolo Vermelho-Escuro distrófico (Santos et al., 2018), i.e., an Oxisol according to Soil Taxonomy (Soil Survey Staff, 1999). In January 2017, soil samples were taken in the 0 to $20 \mathrm{~cm}$ layer to 
analyze fertility level, and the following results were obtained: $\mathrm{pH}\left(\mathrm{H}_{2} \mathrm{O}\right) 5.4,1.3 \mathrm{mg} \mathrm{dm}^{-3} \mathrm{P}\left(\right.$ Mehlich $\left.^{-1}\right), 123$ $\mathrm{mg} \mathrm{dm}{ }^{-3} \mathrm{~K}, 2.6 \mathrm{cmol}_{\mathrm{c}} \mathrm{dm}^{-3} \mathrm{Ca}^{2+}, 0.6 \mathrm{cmol}_{\mathrm{c}} \mathrm{dm}^{-3} \mathrm{Mg}^{2+}$, and $0.0 \mathrm{cmol}_{\mathrm{c}} \mathrm{dm}^{-3} \mathrm{Al}^{3+}$. Based on these results, limestone and potassium fertilization were not performed. Phosphate and nitrogen fertilizations were carried out in January 2017 and 2018, with the application of 50 $\mathrm{kg} \mathrm{ha}^{-1} \mathrm{~N}$ and $50 \mathrm{~kg} \mathrm{ha}^{-1} \mathrm{P}_{2} \mathrm{O}_{5}$. In February 2017 and 2018 , another $50 \mathrm{~kg} \mathrm{ha}^{1-} \mathrm{N}$ were also applied. Urea and simple superphosphate were used as fertilizer sources. The fertilizers were applied in the late afternoon and under cover.

The experiment was conducted in a completely randomized design, with three replicates and four cultivars of $U$. brizantha (Marandu, Xaraés, Piatã, and Paiaguás). The experimental area consisted of 12 experimental plots (units) of $9 \mathrm{~m}^{2}$, three for each cultivar; the four assessed cultivars had already been established in October 2015.

In October 2016, a uniform cut was made in all plots at a height of $5 \mathrm{~cm}$, and plants were grown until reaching $30 \mathrm{~cm}$ (Paula et al., 2012; Nantes et al., 2013; Euclides et al., 2016). This height was maintained until March 2017 through weekly cuts, using pruning shears, in order to mimic a condition of continuous stocking. The excess of forage cut and remaining on the plants was removed from the plots. On March 15, 2017, a 90-day stockpiling period began, which ended on June 13, 2017, during which the plants remained in free growth, without being cut. This stockpiling period corresponded to the first experimental trial in 2017.

A new cut was made to standardize all plants at $5 \mathrm{~cm}$ from the soil surface, representing the second experimental trial, which started in October 2017. Subsequently, the plants were not cut until they reached $25 \mathrm{~cm}$ in height. This height was maintained for all plants, as in the first year, until March 15, 2018, when the stockpiling period began, ending on June 18, 2018, totaling 95 days.

In the two trials, both at the beginning and at the end of stockpiling period, two samples of herbage mass were collected close to the ground of each plot, using a $50 \mathrm{~cm}$ square on the side. The samples were weighed and subdivided into two subsamples. The first was weighed, placed in a forced-air ventilation oven, at $65^{\circ} \mathrm{C}$, for 72 hours, and then weighed again. The second was separated into live leaf blade (live leaf), live stem plus live sheath (live stem), and dead material; these morphological components were also dried in a forced-air ventilation oven, at $65^{\circ} \mathrm{C}$, for 72 hours and weighed. With these data, the masses and morphological compositions of the herbage were calculated at the beginning and end of the stockpiling period. The difference between the herbage masses at the end and beginning of the stockpiling period was divided by the duration of this period, in order to calculate the herbage accumulation rate in $\mathrm{kg} \mathrm{ha}^{-1}$ dry matter (DM) per day.

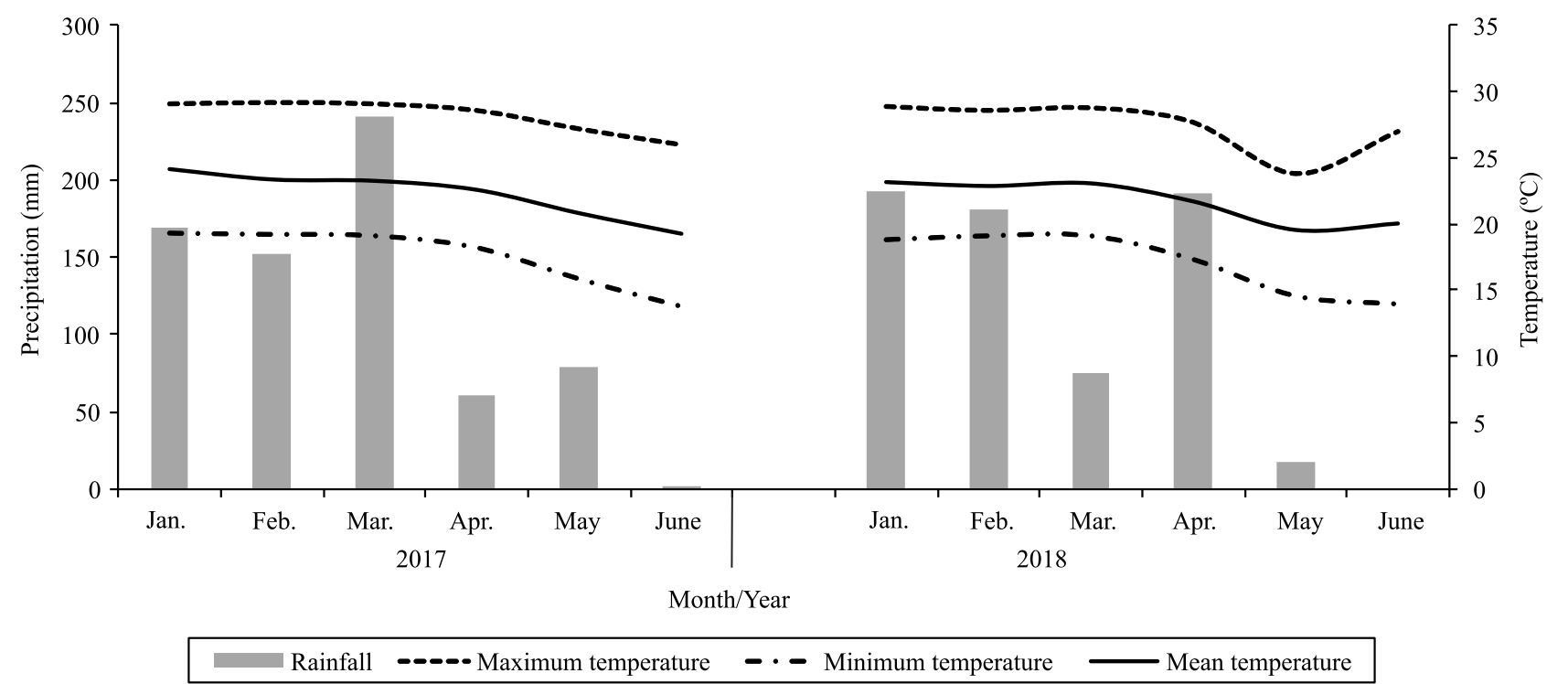

Figure 1. Monthly rainfall and average daily air temperatures from January to June in 2017 and 2018. 
In the two experimental years, the following characteristics were also evaluated at the end of the stockpiling period: canopy height, height of the extended plant, falling index, and population densities of vegetative and reproductive tillers. Canopy height was measured using a graduated ruler, considering the distance between the live leaf horizon and the soil, in ten points per plot. The height of the extended plant was measured at ten points per plot, by extending the grass tillers in the vertical direction and taking note of the distance from the ground level surface to the apex of the highest live leaf in the tillers. The falling index was calculated by the quotient between the average height of the extended plant and the average canopy height.

To evaluate the population density of tillers, vegetative and reproductive tillers were counted within a 50x $25 \mathrm{~cm}$ rectangle at two points in each plot. The vegetative tillers were considered those without visible inflorescence, while the reproductive tillers corresponded to those with visible inflorescence.



Figure 2. Summary of the soil water balance from January to June in 2017 and 2018.
The experimental data were analyzed with the SAS, version 9.0, software (SAS Institute Inc., Cary, NC, USA). The applied model included the fixed effects of the cultivar, experimental year, and their interactions. For each characteristic evaluated, the analysis of variance was performed. When appropriate, the effects of the factor levels were compared using Tukey's test, at $5 \%$ probability.

\section{Results and Discussion}

Herbage mass and number of tillers at the beginning and at the end of the stockpiling period, respectively, were affected by the assessed cultivars (Table 1). In the two study years, even with the maintenance of plants at the same height, the herbage mass at the beginning of the stockpiling period was lower in the canopy of the Paiaguás cultivar, showing that this grass had a forage with a lower volumetric density at the beginning of stockpiling. This distinct canopy structure at the beginning of the stockpiling period, added to the genetic differences between the cultivars, influences the forage accumulation rate and the morphological characteristics of the stockpiled canopies.

The number of vegetative tillers at the end of the stockpiling period was higher in the canopy of the Paiaguás cultivar and lower in that of Xaraés. These results indicate that the Paiaguás cultivar has a greater soil coverage potential than the other ones. The number of vegetative tillers of the Marandu cultivar (702 tillers per square meter) was similar to that reported by Rocha et al. (2021), when studying stockpiled Marandu with different initial heights and nitrogen rates at the same site.

The number of reproductive tillers was higher in the stockpiled canopy of the Xaraés cultivar, intermediate

Table 1. Herbage mass and number of tillers at the beginning and at the end of the stockpiling period, respectively, of Urochloa brizantha cultivars ${ }^{(1)}$.

\begin{tabular}{lcccccc}
\hline Characteristic & \multicolumn{4}{c}{ Cultivar } & P-value & SEM \\
\cline { 2 - 5 } & Paiaguás & Marandu & Xaraés & Piatã & & \\
\hline Herbage mass $\left(\mathrm{kg} \mathrm{ha}^{-1} \mathrm{DM}\right)$ & $3.376 \mathrm{~b}$ & $4.601 \mathrm{a}$ & $4.841 \mathrm{a}$ & $4.534 \mathrm{a}$ & 0.0204 & 378.0 \\
Vegetative tiller per square meter & $1.023 \mathrm{a}$ & $702 \mathrm{~b}$ & $562 \mathrm{c}$ & $645 \mathrm{~b}$ & 0.0021 & 116.5 \\
Reproductive tiller per square meter & $17 \mathrm{~d}$ & $113 \mathrm{~b}$ & $137 \mathrm{a}$ & $81 \mathrm{c}$ & 0.0308 & 30.0 \\
\hline (1) Means followed by equal letters do not differ by Tukey's test, at 5\% probability. HM, herbage mass; DM, dry matter; and SEM, standard error of the \\
mean.
\end{tabular}


in that of Marandu and Piatã, and lower in that of Paiaguás. In the stockpiled canopies, the reproductive tillers corresponded, respectively, to 1.7, 16.1, 24.4, and $12.6 \%$ of the total population density of tillers of the Paiaguás, Marandu, Xaraés, and Piatã cultivars, which can be attributed to the different flowering period of these grasses. As the Paiaguás cultivar has early flowering, it flowered before the stockpiling period when the plants were frequently being cut (Euclides et al., 2016); therefore, it had no stimulus to flower during the stockpiling period, which reduced its number of reproductive tillers. However, the Xaraés cultivar, whose flowering is concentrated in May and June (Flores et al., 2008), when it was in stockpiling (free growth), had a greater number of reproductive tillers. It is worth noting that the number of reproductive tillers in the stockpiled Piatã cultivar was expected to be low due to its earlier flowering season, in January and February (Nantes et al., 2013), which did not occur; this can be justified by the sparse or less intense flowering that usually happens before and after flowering peaks. However, Sousa et al. (2019) observed a low flowering of the Piatã cultivar subjected to stockpiling from March to June. The Marandu cultivar had a higher number of reproductive tillers due to its accentuated flowering during autumn, the season in which its canopy remained without defoliation (stockpiling period). Indeed, Calvano et al. (2011) and Paula et al. (2012), evaluating the Marandu cultivar managed with three average sward heights under continuous stocking, also observed that the number of reproductive tillers was higher in autumn.

The values of the falling index (1.4), live leaf in herbage mass $(21.6 \%)$, and dead material in herbage mass $(47.4 \%)$ were not affected by the studied factors. However, plant height, height of the extended plant, herbage mass, and live stem in herbage mass were affected by the interaction between the studied cultivars and the experimental year (Table 2).

When tropical grasses flower, there is an intense stem elongation and, after inflorescence emission, leaf appearance ceases, which contributes to a decrease in the live leaf/live stem ratio of the stockpiled pasture (Euclides et al., 2008). In this sense, the highest percentage of live stem in the stockpiled Xaraés cultivar, as well as the lowest one in Paiaguás during the first year, may be associated with the number of reproductive tillers. According to Nantes et al. (2013), the stems of the Xaraés cultivar are much thicker than those of Piatã and Marandu, which may also have contributed to its greater live stem percentage.

The obtained results reinforce the positive relationship between flowering and stem participation in stockpiled canopies, which is why it is not recommended to use forage grasses that concentrate flowering during stockpiling (Santos et al., 2018). Therefore, in canopies with a greater predisposition to flowering during the stockpiling period, such as

Table 2. Structural characteristics of Urochloa brizantha cultivars at the end of the stockpiling period during the two experimental years ${ }^{(1)}$.

\begin{tabular}{|c|c|c|c|c|c|c|}
\hline \multirow[t]{2}{*}{ Experimental year } & \multicolumn{4}{|c|}{ Cultivar } & \multirow[t]{2}{*}{ P-value } & \multirow[t]{2}{*}{ SEM } \\
\hline & Paiaguás & Marandu & Xaraés & Piatã & & \\
\hline \multicolumn{7}{|c|}{ Plant height $(\mathrm{cm})$} \\
\hline 2017 & $54.3 \mathrm{bA}$ & $48.7 \mathrm{bA}$ & $67.1 \mathrm{aA}$ & $49.6 \mathrm{bA}$ & \multirow{2}{*}{0.0048} & \multirow{2}{*}{6.1} \\
\hline 2018 & $46.9 \mathrm{aB}$ & $32.6 \mathrm{bB}$ & $47.2 \mathrm{aB}$ & $36.0 \mathrm{bB}$ & & \\
\hline \multicolumn{7}{|c|}{ Height of the extended plant $(\mathrm{cm})$} \\
\hline 2017 & $80.6 \mathrm{bA}$ & $70.5 \mathrm{cA}$ & $93.7 \mathrm{aA}$ & $68.0 \mathrm{cA}$ & \multirow{2}{*}{0.0003} & \multirow{2}{*}{9.2} \\
\hline 2018 & $59.7 \mathrm{aB}$ & $45.3 \mathrm{bB}$ & $60.1 \mathrm{aB}$ & $49.5 \mathrm{bB}$ & & \\
\hline \multicolumn{7}{|c|}{ Herbage mass $\left(\mathrm{kg} \mathrm{ha}^{-1}\right.$ dry matter $)$} \\
\hline 2017 & $9,334 \mathrm{aA}$ & $8,272 \mathrm{bA}$ & $9,894 \mathrm{aA}$ & $8,338 \mathrm{bA}$ & \multirow{2}{*}{$<0.0001$} & \multirow{2}{*}{679.1} \\
\hline 2018 & $7,317 \mathrm{bB}$ & $7,228 \mathrm{bB}$ & $9,116 \mathrm{aA}$ & $6,918 \mathrm{bB}$ & & \\
\hline \multicolumn{7}{|c|}{ Live stem in herbage mass $(\%)$} \\
\hline 2017 & $27.7 \mathrm{cA}$ & $34.5 \mathrm{bA}$ & $46.3 \mathrm{aA}$ & $32.2 \mathrm{bA}$ & \multirow{2}{*}{0.0059} & \multirow{2}{*}{4.0} \\
\hline 2018 & $24.1 \mathrm{aA}$ & $28.5 \mathrm{aA}$ & $27.4 \mathrm{aB}$ & $27.7 \mathrm{aA}$ & & \\
\hline
\end{tabular}

${ }^{(1)}$ Means followed by equal letters, lowercase in the lines and uppercase in the columns, do not differ by Tukey's test, at 5\% probability. SEM, standard error of the mean. 
those of the Xaraés and Marandu cultivars, a decrease in initial sward height and the shortening of the stockpiling period can be management strategies to minimize the flowering of stockpiled pastures.

Tiller death after flowering is usual according to the natural phenological cycle of grass (Santos et al., 2010). This process also contributes to degrade the stockpiled canopy structure, since tiller mortality increases the percentage of dead stems and leaves in the canopy (Santos et al., 2009). In this context, it was expected that the percentage of dead material would be higher in the stockpiled Xaraés cultivar, as it presented a higher number of reproductive tillers. However, the dead material in forage mass did not vary between the assessed $U$. brizantha cultivars and showed an average value of $47.4 \%$. The percentage of live leaf in herbage mass also did not vary between cultivars, with an average value of $21.6 \%$. Moreover, the average values of live stem were 32.5 and $26.9 \%$ in the first and second experimental years, respectively. Silva et al. (2016), evaluating stockpiled pastures of the cultivars Basilisk of signal grass [Urochloa decumbens (Stapf) R.D.Webster] and Marandu during the initial grazing period, also reported similar values for dead material $(51.5 \%)$, live leaf $(26.0 \%)$, and live stem $(22.5 \%)$ in forage mass. Under stockpiled pasture, live stem and dead material percentages are generally high, due to the long period of free growth of grasses, which, consequently, reach a higher development stage (Santos et al., 2010; Silva et al., 2016; Afonso et al., 2018). The high percentages of live stem and dead material in a pasture may hinder herbage selection and gripping and, therefore, limit animal consumption and performance, even when herbage availability is high (Afonso et al., 2018).

In the first year, plant height was higher for the canopy of the Xaraés cultivar, while, in the second, it was higher for that of Xaraés and Paiaguás. In the first year, forage mass was higher for the Xaraés and Paiaguás cultivars; however, in the second, only for Xaraés. These results indicate, in general, that the tallest stockpiled canopies have a higher forage mass, which is in line with the positive correlation between plant height and herbage mass reported by Calvano et al. (2011) for the Marandu cultivar, Carloto et al. (2011) for Xaraés, and Nantes et al. (2013) for Piatã.

The height of the extended plant at the end of the stockpiling period in the first year was higher in the
Xaraés cultivar, intermediate in Paiaguás, and lower in Marandu and Piatã. In the second year, the Xaraés and Paiaguás cultivars also showed a higher height of extended plant at the end of the stockpiling period. Forage grasses with a higher plant height have a greater predisposition to falling, a characteristic that is associated with greater loss of forage during grazing (Santos et al., 2010). However, the falling index of the stockpiled canopies was not influenced by cultivars in the two experimental years and its average value was 1.4 , indicating that the canopies did not cause falling of plants. The falling of stockpiled pasture should be avoided, as the falling index has a positive correlation with the number of reproductive and dead tillers, as well as with indigestible neutral detergent fiber contents (Santos et al., 2010), characteristics that contribute to a worst structure and nutritional value of stockpiled pasture.

The values for the herbage accumulation rate during the stockpiling period were affected by the assessed cultivars, being higher for Paiaguás and Xaraés (Figure 3). Likewise, Euclides et al. (2016) compared the structure and the herbage accumulation rate of pastures of the Paiaguás and Piatã cultivars and verified, during the dry period (autumn and winter), that Paiaguás also presented a higher herbage accumulation rate, as well as a higher percentage of live leaf in herbage mass.

The high herbage accumulation rate values of the Xaraés cultivar may be related to its greater genetic potential for herbage production (Flores et al., 2008).

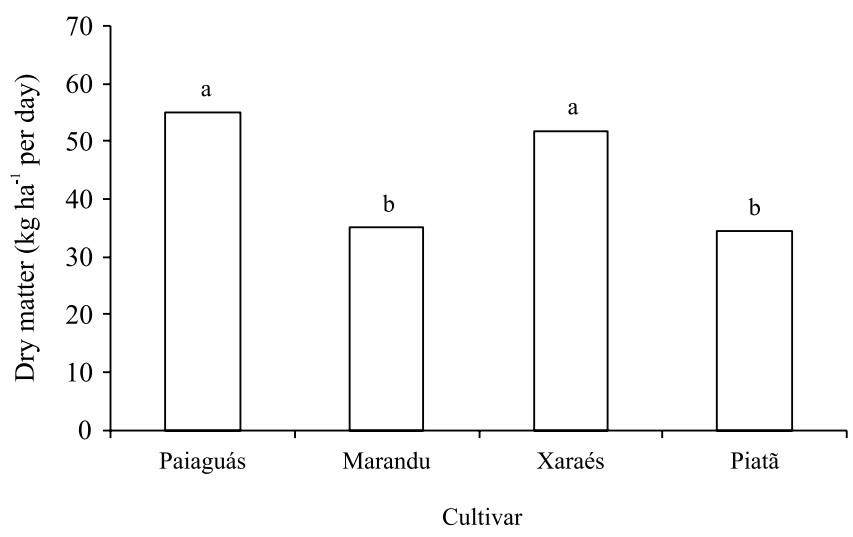

Figure 3. Herbage accumulation rate of Urochloa brizantha cultivars during the stockpiling period (average of the two experimental years). Bars with equal letters do not differ by Tukey's test, at 5\% probability. 
Indeed, in a study conducted by Rodrigues et al. (2012) to identify functional groups of tropical forage grasses through morphogenic and structural characteristics, the Xaraés cultivar was grouped with Mombaça [Panicum maximum Jacq. Syn. Megathyrsus maximus (Jacq.) B.K.Simon \& S.W.L.Jacobs], a forage grass cultivar known to have a high herbage production potential (Alvarenga et al., 2020).

The values for the herbage accumulation rate obtained in the present study were lower than those of 49.3 and $56.7 \mathrm{~kg} \mathrm{ha}^{-1} \mathrm{DM}$ per day reported by Montagner et al. (2013) and Paula et al. (2012) for the Piatã and Marandu cultivars, respectively, managed under continuous stocking during autumn. The differences in the values obtained for the herbage accumulation rate are due to the different climatic and management conditions of each study.

Since the climatic conditions differed between the experimental years, rainfall during the stockpiling period was higher in the first year $(253.7 \mathrm{~mm})$, compared with the second $(233.8 \mathrm{~mm})$ (Figure 1). In effect, the average value of the soil water balance in the months in which stockpiling occurred (March to June) was also higher in the first $(6.6 \mathrm{~mm})$ than in the second $(-15.3 \mathrm{~mm})$ year (Figure 2). The lowest water scarcity during the first year resulted in a higher number of vegetative (851 tillers per square meter) and reproductive (121 tillers per square meter) tillers, when compared with the second year (615 vegetative and 53 reproductive tillers per square meter). The lower water deficit in the soil in the first year was also responsible for the higher values for plant height, height of the extended plant, and forage mass (except for the Xaraés cultivar). As a consequence, the herbage accumulation rate was higher in the first year $\left(49.0 \mathrm{~kg} \mathrm{ha}^{-1} \mathrm{DM}\right.$ per day), in comparison with the second $\left(39.1 \mathrm{~kg} \mathrm{ha}^{-1}\right.$ DM per day). These results show that stockpiling is significantly influenced by the climate, which can vary between years. Therefore, this characteristic must be considered when planning the use of this strategy in a production system.

Differences were observed in the herbage accumulation and structural characteristics of the stockpiled Marandu, Piatã, Xaraés, and Paiaguás cultivars. Although all of these cultivars can be used for stockpiling, Paiaguás stands out for its high potential for herbage production during the stockpiling period (autumn), which results in a stockpiled canopy with a better structure. The Xaraés cultivar also produces a high amount of herbage mass during the stockpiling period, but its higher number of reproductive tillers and percentage of live stem in the forage mass may limit animal consumption (Benvenutti et al., 2008). Therefore, the Xaraés cultivar is recommended when the goal is to work with a high stocking rate in the stockpiled pasture during the dry season.

\section{Conclusions}

1. In the stockpiling period, the Paiaguás and Xaraés cultivars of Urochloa brizantha have a greater herbage accumulation than Piatã and Marandu.

2. The stockpiled Paiaguás cultivar has a higher number of vegetative tillers and a lower one of reproductive tillers, conferring it a better structure than that of Piatã, Xaraés, and Marandu.

\section{Acknowledgments}

To the members of Grupo de Testes de Hipóteses em Forragens (TESTHFOR) of Universidade Federal de Uberlândia (UFU), for their contributions during the field trial setup.

\section{References}

AFONSO, L.E.F.; SANTOS, M.E.R.; SILVA, S.P.; RÊGO, A.C.; FONSECA, D.M.; CARVALHO, B.H.R. O capim-marandu baixo no início do diferimento melhora a morfologia do pasto e aumenta o desempenho dos ovinos no inverno. Arquivo Brasileiro de Medicina Veterinária e Zootecnia, v.70, p.1249-1256, 2018. DOI: https://doi.org/10.1590/1678-4162-10130.

ALVARENGA, C.A.F; EUCLIDES, V.P.B.; MONTAGNER, D.B.; SBRISSIA, A.F.; BARBOSA, R.A.; ARAÚJO, A.R. de. Animal performance and sward characteristics of Mombaça guineagrass pastures subjected to two grazing frequencies. Tropical Grasslands - Forrajes Tropicales, v.8, p.1-10, 2020. DOI: https://doi.org/10.17138/tgft(8)1-10.

ALVARES, C.A.; STAPE, J.L.; SENTELHAS, P.C.; GONÇALVES, J.L. de M.; SPAROVEK, G. Köppen's climate classification map for Brazil. Meteorologische Zeitschrift, v.22, p.711-728, 2013. DOI: https://doi.org/10.1127/09412948/2013/0507.

ALVES, L.C.; SANTOS, M.E.R.; PEREIRA, L.E.T.; CARVALHO, A.N. de; ROCHA, G. de O.; CARVALHO, B.H.R.; VASCONCELOS, K.A.; ÁVILA, A.B. Morphogenesis of age groups of Marandu palisade grass tillers deferred and fertilised with nitrogen. Semina: Ciências Agrárias, v.40, p.2683-2692, 2019. DOI: https://doi.org/10.5433/1679-0359.2019v40n6p2683. 
BENVENUTTI, M.A.; GORDON, I.J.; POPPI, D.P. The effects of stem density of tropical swards and age of grazing cattle on their foraging behaviour. Grass and Forage Science, v.63, p.1-8, 2008. DOI: https://doi.org/10.1111/j.1365-2494.2007.00609.x.

CALVANO, M.P.C.A.; EUCLIDES, V.P.B.; MONTAGNER, D.B.; LEMPP, B.; DIFANTE, G. dos S.; FLORES, R.S.; GALBEIRO, S. Tillering and forage accumulation in Marandu grass under different grazing intensities. Revista Ceres, v.58, p.781-789, 2011. DOI: https://doi.org/10.1590/s0034-737x2011000600015.

CARLOTO, M.N.; EUCLIDES, V.P.B.; MONTAGNER, D.B.; LEMPP, B.; DIFANTE, G. dos S.; PAULA, C.C.L. de. Desempenho animal e características de pasto de capim-xaraés sob diferentes intensidades de pastejo, durante o período das águas. Pesquisa Agropecuária Brasileira, v.46, p.97-104, 2011. DOI: https://doi.org/10.1590/s0100-204x2011000100013.

EUCLIDES, V.P.B.; MACEDO, M.C.M.; VALLE, C.B. do; BARBOSA, R.A.; GONÇALVES, W.V. Produção de forragem e características da estrutura do dossel de cultivares de Brachiaria brizantha sob pastejo. Pesquisa Agropecuária Brasileira, v.43, p.1805-1812, 2008. DOI: https://doi.org/10.1590/s0100$204 \times 2008001200023$.

EUCLIDES, V.P.B.; MONTAGNER, D.B.; BARBOSA, RA.; VALLE, C.B. do; NANTES, N.N. Animal performance and sward characteristics of two cultivars of Brachiaria brizantha (BRS Paiaguás and BRS Piatã). Revista Brasileira de Zootecnia, v.45, p.85-92, 2016. DOI: https://doi.org/10.1590/s180692902016000300001.

FLORES, R.S.; EUCLIDES, V.P.B.; ABRÃO, M.P.C.; GALBEIRO, S.; DIFANTE, G. dos S.; BARBOSA, R.A. Desempenho animal, produção de forragem e características estruturais dos capins marandu e xaraés submetidos a intensidades de pastejo. Revista Brasileira de Zootecnia, v.37, p.1355-1365, 2008. DOI: https://doi.org/10.1590/s1516-35982008000800004.

GOUVEIA, F. de S.; FONSECA, D.M. da; SANTOS, M.E.R.; GOMES, V.M.; CARVALHO, A.N. de. Altura inicial e período de diferimento em pastos de capim-braquiária. Ciência Animal Brasileira, v.18, e-43744, 2017. DOI: https://doi.org/10.1590/1809$6891 v 18 \mathrm{e}-43744$.

MONTAGNER, D.B.; EUCLIDES, V.P.B.; GENRO, T.C.M.; NANTES, N.N. Dry matter intake by beef steers on Piatã palisadegrass (Brachiaria brizantha cv. BRS Piatã) pasture. Tropical Grasslands - Forrajes Tropicales, v.1, p.106-108, 2013. DOI: https://doi.org/10.17138/tgft(1)106-108.

NANTES, N.N.; EUCLIDES, V.P.B.; MONTAGNER, D.B.; LEMPP, B.; BARBOSA, R.A.; GOIS, P.O. de. Desempenho animal e características de pastos de capim-piatã submetidos a diferentes intensidades de pastejo. Pesquisa Agropecuária Brasileira, v.48, p.114-121, 2013. DOI: https://doi.org/10.1590/ s0100-204x2013000100015.

NAVE，R.L.G.; BARBERO, R.P.; BOYER, C.N.; CORBIN, M.D.; BATES, G.E. Nitrogen rate and initiation date effects on stockpiled tall fescue during fall grazing in Tennessee. Crop, Forage \& Turfgrass Management, v.2, p.1-8, 2016. DOI: https://doi.org/10.2134/cftm2015.0174.
NOGUEIRA, H.C.R.; SANTOS, M.E.R.; CARVALHO, B.H.R.; CARVALHO, A.N. de; VASCONCELOS, K.A.; ROCHA, G. de O. Initial height and nitrogen fertilisation on deferred pastures of marandu palisadegrass. Semina: Ciências Agrárias, v.41, p.959-970, 2020. DOI: https://doi.org/10.5433/16790359.2020v41n3p959.

PAULA, C.C.L.; EUCLIDES, V.P.B.; MONTAGNER, D.B.; LEMPP, B.; DIFANTE, G.S.; CARLOTO, M.N. Estrutura do dossel, consumo e desempenho animal em pastos de capim-marandu sob lotação contínua. Arquivo Brasileiro de Medicina Veterinária e Zootecnia, v.64, p.169-176, 2012. DOI: https://doi.org/10.1590/s0102-09352012000100024.

ROCHA, G. de O.; CARVALHO, B.H.R.; OLIVEIRA, D.M. de; MORAES, L.D. de; SANTOS, M.E.R. Characterization of vegetative and reproductive tillers as a basis to recommend heights and nitrogen doses for the stockpillage of Marandu palisade grass. Veterinária Notícias, v.27, p.1-14, 2021. DOI: https://doi.org/10.14393/VTN-v27n1-2021-55928.

ROCHA, G. de O.; SANTOS, M.E.R.; VILELA, H.H.; CARVALHO, B.H.R.; SOUSA, B.M. de L.; FAGUNDES, J.L.; BACKES, A.A.; FONTES, P.T.N. Structure of piatã palisadegrass deferred for two periods and fertilised with nitrogen. Semina: Ciências Agrárias, v.41, p.995-1006, 2020. DOI: https://doi.org/10.5433/1679-0359.2020v41n3p995.

RODRIGUES, C.S.; NASCIMENTO JÚNIOR, D. do; DETMANN, E.; SILVA, S.C. da; SOUSA, B.M. de L.; SILVEIRA, M.C.T. da. Grupos funcionais de gramíneas forrageiras tropicais. Revista Brasileira de Zootecnia, v.41, p.1385-1393, 2012. DOI: https://doi.org/10.1590/s1516-35982012000600010.

SANTOS, M.E.R.; FONSECA, D.M. da; EUCLIDES, V.P.B.; NASCIMENTO JÚNIOR, D. do; QUEIROZ, A.C. de; RIBEIRO JÚNIOR, J.I. Características estruturais e índice de tombamento de Brachiaria decumbens cv. Basilisk em pastagens diferidas. Revista Brasileira de Zootecnia, v.38, p.626-634, 2009. DOI: https://doi.org/10.1590/S1516-35982009000400006.

SANTOS, M.E.R.; FONSECA, D.M. da; OLIVEIRA, I.M. de.; CASAGRANDE, D.R.; BALBINO, E.M.; FREITAS, F.P. Correlações entre número de perfilhos, índice de tombamento, massa dos componentes morfológicos e valor nutritivo da forragem em pastos diferidos de capim-braquiária. Revista Brasileira de Zootecnia, v.39, p.487-493, 2010. DOI: https://doi.org/10.1590/s1516-35982010000300006.

SANTOS, M.E.R. dos; FONSECA, D.M. da; SOUSA, B.M. de L.; ROCHA, G. de O.; CARVALHO, A.N. de; CARVALHO, R.M.; CARVALHO, B.H.R. Todo ano tem seca. Está preparado? In: RESENDE, F.D. de; SIQUEIRA, G.R.; OLIVEIRA, I.M. de (Ed.). Entendendo o conceito Boi 777. Jaboticabal: Gráfica Multipress Ltda., 2018. p.107-121.

SILVA, C.S.; MONTAGNER, D.B.; EUCLIDES, V.P.B.; QUEIROZ, C. de A.; ANDRADE, R.A.S. Steer performance on deferred pastures of Brachiaria brizantha and Brachiaria decumbens. Ciência Rural, v.46, p.1998-2004, 2016. DOI: https://doi.org/10.1590/0103-8478cr20151525. 
SOIL SURVEY STAFF. Soil taxonomy: a basic system of soil classification for making and interpreting soil surveys. $2^{\text {nd }}$ ed. Washington: USDA, NRCS, 1999. 866p.

SOUSA, B.M. de L.; SANTOS, M.E.R.; AMORIM, P.L. de; SILVEIRA, M.C.T. da; ROCHA, G. de O.; CARVALHO, A.N. de. Effect of nitrogen fertilization on structure and tillering dynamics of Piata palisade grass during the deferment period. Semina: Ciências Agrárias, v.40, p.249-258, 2019. DOI: https://doi.org/10.5433/1679-0359.2019v40n1p249.

SOUSA, B.M. de L.; SANTOS, M.E.R.; VILELA, H.H.; SILVEIRA, M.C.T. da; ROCHA, G. de O.; FREITAS, C.A.S.; SILVA, N.A.M. da; NASCIMENTO JÚNIOR, D. do. Piata palisade grass deferred with two distinct initial heights: luminous environment and tillering dynamics. Revista Brasileira de Zootecnia, v.42, p.36-43, 2013. DOI: https://doi.org/10.1590/ S1516-35982013000100006.

THORNTHWAITE, C.W.; MATHER, J.R. The water balance. Centerton: Drexel Institute of Technology Climatology, 1955. 104p.

VALLE, C.B. do; EUCLIDES, V.P.B.; PEREIRA, J.M.; VALÉRIO, J.R.; PAGLIARINI, M.S.; MACEDO, M.C.M.; LEITE, G.G.; LOURENÇO, A.J.; FERNANDES, C.D.; DIAS FILHO, M.B.; LEMPP, B.; POTT, A.; SOUZA, M.A. de. O capimxaraés (Brachiaria brizantha cv. Xaraés) na diversificação das pastagens de braquiária. Campo Grande: Embrapa Gado de Corte, 2004. 36p. (Embrapa Gado de Corte. Documentos, 149). 